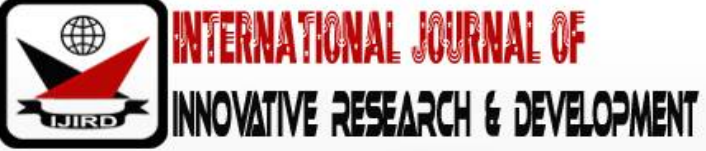

ISSN 2278 - 0211 (Online)

\section{Influence of Mobile Phone Use on Secondary Schools Students' Discipline, in Moshi Municipality, Kilimanjaro, Tanzania}

\begin{tabular}{c} 
Dr. Gadi M. Koda \\
Lecturer, Department of Education (Directorate of Postgraduate), \\
Mwenge Catholic University, Tanzania \\
James Kayombo \\
Master Student, Directorate of Postgraduate, Mwenge Catholic University, Tanzania \\
\hline
\end{tabular}

\begin{abstract}
:
Discipline is a key component in teaching and learning process. A good academic qualification without a good foundation of discipline of the students is of no use to the individual, school, their families and the society. The purpose of this study was to investigate on the influence of mobile phone use on secondary schools' students' discipline in Moshi, Municipality-Kilimanjaro, Tanzania. The study was guided by six research questions. The theoretical framework used Bandura's social learning theories (1977). The conceptual framework shows the influence of mobile phone on the behaviour/discipline of secondary school students. The study employs Quantitative approach, and Ex post facto designs to collect information about participants' views concerning mobile phone influence on students' discipline. The target population included all students, teachers, school board members and parents in Moshi Municipality, Kilimanjaro region, Tanzania. The researcher used sample size of 184 respondents, whereby the students were only form three and form four with total sample of 128 students, 32 teachers, 8 discipline masters, 8 school board chairpersons, and 8 parents' representatives. To get this sample the study employed stratified random sampling, simple random sampling, automatic random sampling and purposive sampling. Questionnaire was used as the main instrument of data collection, in addition document analysis guide was employed to get some findings to complement findings from the instrument mentioned prior and verify its realities. Furthermore, in this study frequency, percentage and mean scores were used to analyze data. The hypothesis was tested using Chi square and split -half method was used to test reliability of instruments. All these were done under the aid of Statistical package for Social Sciences (SPSS) version 22 . The study found that there is significance relationship between students' mobile phone use and their behaviours in Secondary schools in Moshi Municipal.
\end{abstract}

Keywords: Mobile phone, student's discipline (behavior)

\section{Introduction and Background}

Students' disciplinary problem has been a major concern in schools and a major challenge facing teachers at school and society at large. Students as key stakeholders and the most essential resources in education it is absolutely necessary to direct them to exhibit acceptable attitude and behaviour within and outside the school. It has been noted that these disciplinary problems can be the main hindrance to effective teaching and learning. In an attempt to achieve an organized and peaceful school environment and maintain law and order, school management specifies rules and regulations to guide the activities of members of the educational institution as sound education can be provided when there is discipline in schools.

The aim and objectives of the education and training policy in Tanzania are stated as meant to inculcate a sense of self confidence, to develop enquiring minds in students to develop respect for human dignity and to make students socially responsible for the national welfare (Ministry of Education \& Vocational Training [MoEVT], 1995).

In order to make a good society the school can be seen as a workshop over the individual. Character comprises the willing of the individual for goodness of other people and moral thought, behaviours for being honest and responsible, personal and affective properties of the one across various circumstances for creating effective approaches, and affective commitment of the individual. Good character helps people to have a democratic life style which includes being equal and respectful to other people and being able to add positive values to the society (Battistich, 2005).

Poor discipline in schools creates violence and unsafe environment within a school community resulting in lower achievement rates. Indiscipline in schools often includes truancy, drug abuse, peddling drugs, bullying, drinking alcohol, smoking, sexual affairs, abusive language, bad dressing style and theft. Simatwa (2002) noted that the major aim of discipline both in school and at home should be to nurture young people who will be responsible citizens in future. The aim of school discipline should therefore be seen to help students cope well, be happy, safe and useful to the society they belong. 
According to Jeng (2011), explain that knowledge without discipline is useless. It is only knowledge alongside discipline that one can use to get anything in life, for it is the only weapon that one can use to fight against poverty, harassment, difficulties, violence and discrimination in our society. A disciplined and educated people (student) become a progressive element in the society. Therefore, students must maintain discipline to earn dignity and success.

Indiscipline has been a major concern all over the world, for example, India Parenting online Ltd (2007) as quoted by Ndeto (2013) reported the standards of discipline to be worsening in Indian secondary schools. The study pointed out that there was a need to find a lasting solution to the problem of indiscipline. The solution to the issue of indiscipline would make student's education and schooling experience more productive.

Also, the same cases of indiscipline have also been noted in England. There was a case in one school where a student happened to be carrying a gun in direct contravention of school rules which prohibits carrying of any form of weapon to school. He used it to shoot a fellow student. The government then planned a crackdown on school indiscipline by giving schools powers to search pupils with weapons (Hannah, 2010).

Likewise, the schools in Botswana had their image spoiled by acts of student indiscipline. Some students died and others became blind after they broke into the school science laboratory and consumed toxic amounts of methanol and ethanol (Simatwa, 2012)). A survey on a number of previous provincial schools also pointed out that indiscipline had caused deterioration in academic performance.

There are reports of some serious misbehaviour among secondary school students in Tanzania. The common unacceptable behaviours that mostly manifested in Tanzanian secondary schools, include truancy, disobeying school administration, failure to maintain self cleanliness and school cleanliness, being late to school, sexual behaviours and failure to live in peace and order engaging in alcoholism (Izahak, 2006).

Despite rules and regulations in schools, there have been acute truancy problems in secondary schools in Tanzania. The teenagers in secondary schools are no longer obeying their teachers and fellow students. The Ministry of Education noted in the rate of students' indiscipline in Tanzania in secondary schools which were revealed through breach of school rules, absenteeism, destruction of school and private property, use of illegal drugs, use of alcohol and engagement in sexual practices (URT, 2011).

In BEST, (2011) 76,002 students drop out in secondary schools for indiscipline reasons which includes; truancy 55,267 students (72.1\%), pregnancy 5,157students (6.8\%) and other misbehaviour 2879 students (3.8). These show how indiscipline is a problem in Tanzania, the remaining 10,532 students (13.7\%) dropped out in the same year due to parent failure to meet students needs (BEST, 2011). These reflect lack of follow up for teachers in schools and neglect from the authority in noting the problems facing students before they decide to quit the school environment. This study sought to find out how to eliminate this problem of misbehaviour through new technology.

New technology innovations have turned the world into global village. There are potential benefits associated with the use of internet for educational, shopping and banking transactions, medical intervention, and communication in the form of e-mail, instant message and chatting. Mobile phone became one of the Information and Communication Technology (ICT) tools that have turned the world into a global village through easy access to information. The positive contribution of the use of mobile phones in economic, political and social aspects of every society has led some scholars to advocate the adoption as a tool in teaching and learning process (Aguero, 2009). Likewise, Leyden (2015), identify 40 ways through which mobile phones could be used to facilitate learning among which are; checking of facts related to academic work, taking photos to illustrate work and presentation, using as dictionary, calendar, reading e-books, calculator, Television -TV, radio, reading currents news related to learning, mention a few.

However, while the mobile phone through internet provides a wealth of positive information, it is said that there has been increased awareness of its potential dangers, especially to young people (Kwajo, 2011). The internet is increasingly becoming a monster in the content that included in it. Using social media networks, content shared original media such as photo and videos. Some scholars argued that mobile phones are very useful gadgets, but when smuggled into school, may be a source of severe indiscipline. Majority of students carry their mobile phones to school. For example, Kwajo (2011) argued that mobile phones can be a source of great misconduct in schools, among them, viewing pornography and cheating in exams.

In many countries including Tanzania, most of the schools ban students from using mobile phone in school environments. There are strict policies, which are stipulated in school rules and regulations which prohibit students from accessing mobile phones. Burning \& Moss (2012) argued that banning of mobile phones aims at improving students' behaviour. Most of the schools ban students from using mobile phones; they argue that students spent a lot of time chatting, recording fights, watching pornography and chatting through social networks instead of concentrating to their studies and home works given at school.

Despite the banning of mobile phones in schools, parents provide mobile phone to their children, also other students bought the mobile phone using their pocket money and from partners who involve them with sexual affairs. For example, the study conducted by Twebaze (2015) in rural district of Bushenyi in Uganda found that the majority of the students $(85 \%)$ who agreed they owned mobile phones said they had been given to them by their parents while the rest said they had bought them on their own or been offered them by relatives.

From these arguments, teachers, administrators and parents seem not to be aware of what is destructing their students which lead to indiscipline which later may impact their academic performance, and the community at large. Therefore, given that Secondary schools are faced by all these problems, the researchers felt that something wrong was happening to the students' behaviour and could be attributed to the mobile phone saturation in the society. Therefore, these effects needed to be brought to the fore through an investigation, hence the necessity of carrying out a research on 
the information from secondary schools' students, teachers and parents about their knowledge on influence of mobile phone use on students' discipline (both positive and negative) in Moshi municipality, Tanzania.

In Tanzania secondary school students' behaviour has become questionable by education administrators, teachers and parents. Parents and other stakeholder are lamenting teachers for students' indiscipline in secondary schools in Tanzania. Although schools play an important role in the socialization process of the young people from where they learn to regulate their own conduct, respect towards others, manage their time responsibly and thus becoming responsible citizens. The study looks at it in technological perspective thus mobile phone use might be the cause as, some parents, stakeholders and literature say. For example, Kwajo (2011), associate indiscipline in relation to students' mobile phone use hence ignore the use of mobile phone in schools, though others advocate mobile phone to be used in secondary school as a learning gadget like (Aguero, 2011 \& Leyden, 2015).

Studies reviewed have different focus on student's mobile phone use in schools which bring confusion where to stand at. Some of them try to investigate on social media in general without being specific to one device like mobile phone with students' behaviour. Though they relate social media with students' discipline but they focus much on specific negative behaviour generally on sexual behaviour, for example (Geoffrey, 2014). Others related mobile phone with performance and they came up with single reasons of failure that students spend a lot of time on the device and forget studying hence failure. They forget other behaviour that can be influenced by students' mobile phone use which can lead to students' performance or failure, for example (Almu \& Buhar, 2014; Lepp et.al, 2015). Other studies suggest the ban of students using mobile phone in schools should be removed but they didn't investigate on the danger that can be raised, others ignore students to be allowed to use mobile phone, for example, (Disney Cooperation, 2007). As all of them fail to show how magnitude mobile phone use can influence students' behaviour being positive or negative. Therefore, this study sought to fill these gapes and investigated to what extent students' mobile phone influence secondary schools' students' discipline in Moshi Municipality, Tanzania.

\section{Literature Review}

Review of literature to the study began with explanations of different theories which are related to the study. It also provided the related empirical studies which were done by different researchers. Lastly the chapter ended by giving a summary of the literature reviewed and knowledge gaps between previous studies and the current study. The study applied the theory of B.F Skinner (1938) who brought up the idea of operant conditioning. Operant condition can be described as a process that attempts to modify behaviour through the use of positive and negative reinforcement. Through Operant Condition, an individual makes an association between a particular behaviour and a consequence. Skinner believed that one should focus on the external observable causes of behaviour rather than trying to unpack the internal thoughts and motivations.

\subsection{Strength of the Theory}

It is very helpful way to control students' behaviour. Thus, when students are misbehaving a punishment should be given and good behaviour should be rewarded.

\subsection{Weakness of the Theory}

Strictly deal with distinct behaviour good or bad. It focuses much on reward for good behaviour and punishment for bad behaviour. This means if the child behaves in a good manner receive reward what if is not rewarded it means will stop behaving in a good manner.

\subsection{Uses and Gratification Theory}

Uses and Gratifications Theory developed by J. Blumler \& D. McQuail (1974) is a popular approach to understanding mass communication. The theory places more focus on the consumer, or audience, instead of the actual message itself by asking what people do with media rather than what media does to people (Katz, 1974). It assumes that individuals have power over media usage, rather than positioning individuals as passive consumers of media. It explores how individuals deliberate seek out media to fulfil certain needs or goals such as entertainment, relaxation, learning or socialization, information sharing, pass time, and knowledge about others.

\subsection{Strengths of Uses and Gratification Theory}

This theory is the most influential in the field of communication research, its ability to allow researchers to study mediated communication situations via single or multiple sets of psychological needs, psychological motives, and communication channels, communication content and psychological gratifications within a particular or cross-cultural context (Blumler\& Katz's, 1974).

\subsection{Weakness of Uses and Gratification Theory}

The theory does not consider the power of media, thus how students watch the content in mobile phones not because the media is popular but because what they observe, they use it for different needs, such as more realistic, entertain, sensational and interesting. 


\subsection{Review of Empirical Studies}

Mobile phones are getting smarter and the usage through school students becoming more popular. Students using mobile phones for talking, texting message, internet search, listening music, watching videos, playing games, using social media and so on though it has been banned from school. Mobile phones are not accessories anymore; they are integrated like our clothes. There are studies examining how students integrate mobile phone use in schools and their influence to students in school environment.

For example, the study done by Geoffrey (2014) examine the influence of media on secondary school students' sexual behaviour, found that the most preferred media was observed to be Television. This media through internet, news papers, magazine, radio, mobile phone and television has been observed to influence school students" involvement in sexual intercourse earlier. Also, the study revealed that female secondary school students are more sexually active than their counterpart male students. In addition to the above findings, the study found that parents who control their children on mass-media use are fewer than those who do not.

Therefore, the study focuses much on all media in general, and not specifically to mobile phone how it influences students' behaviour. The study also focuses only on sexual behaviour and forgets about other students' behaviour that can be influenced by a specific media like violence, drug abuse and so on. Therefore, the study fails to identify the positive and other negative behaviour that can be due to mobile phone use.

Study done by Twebaze, (2015), carried out in a rural district of Bushenyi in Uganda where the researcher sought to establish the usage of mobile phones among secondary school students in boarding schools. The researcher also sought the views and opinions of students, teachers and parents about the use of mobile phones by students in the schools. The study established that despite the official ban on use of mobile phones by students in school, $34 \%$ of the students said they were aware that some students own and use mobile phones in school. It was further established that $40 \%$ of teachers said they were aware that some students owned and used phones in school while $20 \%$ of them supported the use of phones by the students. Meanwhile, $40 \%$ of the parents supported the use of mobile phones by students in school. It was noted that the battle against the use of mobile phones by students in secondary schools might soon be lost due to the increased availability and benefits associated with their use.

The study focuses on the establishment of students' mobile phone use in school, some teachers and students accept to remove the ban and others ignore it. This brings confusion on what is to be done. The good way to suggests introduction of mobile phones use in schools the researcher could have investigate on students' mobile phone use and its influence on behaviour change either bad or good by investigating from different groups (teachers, students and parents). This could have been of help by coming up with clear evidence of accepting students' mobile phone use or ignore it.

A study conducted by Disney Cooperation, (2007) on "Teen and Tween Cell Phone calls rise during the summertime", using 1,500 students between the ages of 10-17 found during the summer a student spent an average of 3 hours and 45 minutes using their cell phones each day. One third of students researched say they would rather give up video games or even a trip to the mail before parting with their cell phones. One fifth of students reported they would rather give up phones watching television than their cell. The study suggests the use of cell phones by students as a tool for classroom instruction. Students enjoy using their cell phones and they are highly motivated to interact with their cell phones for more than just communicating with friends. Most students have their cell phones with them at all times. However, the researchers fail to investigate what contents students accessed from the mobile phone, and how it influences their behaviour negatively or positively. They only suggest to be used as an ICT tool in learning activities without considering the effects of it.

The study done by Almu \& Buhari (2014) in Sokoto Nigeria on "Effect of Mobile Social Network on Secondary schools", the aim of this study was to assess the trend of mobile social networks usage among secondary schools' student within Sokoto metropolis and how it affects their academic performance. The research was conducted in some selected secondary schools consisting of students aged 14 to 19. The experimental result revealed that, mobile social networks typically affects most of the student performance that are addicted to mobile social networking sites, especially those that cannot spend even a day without visiting the sites. The study recommends that, mobile social network can be very useful device for supporting learning activities to the students, provided there is appropriate guidance and monitoring from both parents and teachers.

However, the study did not focus much on what other behaviour different from spending a lot of time using mobile phone, are being developed. Also, the study focuses only one specific behaviour change, poor performance and come up with the recommendation of using this device in learning activities. The methodology used was experimental; he could have identified a lot on behaviours observed by the respondents. Therefore, the study fails to identify other negative behaviours associated with students using mobile phone, like developing sexual behaviour, violence and so on.

The study conducted by Lepp et.al (2015) was done among a sample of US college students on the use of mobile phone and students' performance, reported that increased cell phone use was associated with decreased academic performance and recommended that there was need to sensitize students and educators about the potential academic risks associated with high frequency cell phone use. However, other teachers argue that it is not necessary to keep pushing against technology so schools should embrace the use of phones to avoid further separation from students. They advocate incorporation and collaboration to see how best phones can be used rather than banning and punishment.

The study bring confusion as some of the students and educators argue that there are potential risks to students frequently using mobile phones and the other argue that it is not necessary to keep avoiding new technology because we live on it. The study also focuses on college students; thus, the researcher could have observed also secondary school students whom they seem to be in adolescent stage, they can't reason careful compare to college students. 


\subsection{Summary of Literature Review and Knowledge Gap}

Studies reviewed have different focus on students' mobile phone use in schools which bring confusion where to stand at. Some of them try to investigate on social media in general without being specific to one device like mobile phone with students' behaviour. Though they relate social media with students' discipline but they focus much on specific negative behaviour generally on sexual behaviour, for example, (Geoffrey, 2014). Others related mobile phone with performance and they come up with single reasons of failure that students spend a lot of time on the device forget studying hence failure. They forget other behaviour that can be influenced by students' mobile phone use which can lead to students' performance or failure, for example (Almu \& Buhar, 2014; Lepp et.al, 2015). Other studies suggest the ban of students using mobile phone in schools should be removed but they didn't investigate on the danger that can be raised, and others ignore students to be allowed to use mobile phone, for example, (Disney Cooperation, 2007). As both of them fail to show how magnitude mobile phone use can influence students' behaviour being positive or negative, therefore the researcher in this study investigated to what extent students' mobile phone influence secondary school students' discipline in Moshi Municipality, Tanzania.

\section{Research Methodology}

The study employed quantitative research paradigm using Ex-post-facto. The researchers use Ex post facto design because it enables researchers to test cause and effect of phenomena (mobile phone use and students' discipline) where it was not practical or ethical to apply a true experimental or quasi-experimental design. This was through its meaning that is systematic empirical inquiry in which the scientist does not have direct control of independent variables because their manifestations have already occurred or because they are inherently not manipulated. With this concept the relations among variables will be made without direct intervention, from co-commitment variation of independent and dependent variables. Thus, the students have already used mobile phone and it affects their behaviours, the researcher want to investigate the ones who experience it. As it is inhuman to expose the students to mobile phone and become affected.

Data was therefore collected using self-administered instruments namely questionnaires and document Analysis Schedule as the principal data collecting instruments. The questionnaires were used because they are cheap to administer to respondents scattered over a large area and also convenient for collecting information from a large population within a short period of time (Dempsey \& Dempsey, 2000).

\section{Discussion and Interpretation of Findings, Questionnaire Return Rate}

\begin{tabular}{|c|c|c|c|}
\hline Participants & Expected Numbers & Actual numbers & Percentages \\
\hline Students & 128 & 128 & 100 \\
\hline Teachers & 32 & 32 & 100 \\
\hline Discipline teachers & 8 & 8 & 100 \\
\hline School boards chairpersons & 8 & 8 & 100 \\
\hline Parents representatives & 8 & 8 & 100 \\
\hline
\end{tabular}

Table 1: Summary of Information of Respondents

Source: Field Data, 2017

The findings in Table 1 indicate that all participants (students, teachers, parents' representatives, discipline teachers, and school boards chairpersons) who were sampled participated in the study, returned the questionnaire to the researcher which made $100 \%$ of expected respondents.

\subsection{Students' Disciplinary Cases Experienced in Secondary Schools in Moshi Municipality}

In the first research question the researcher wanted to find out if there are disciplinary cases in schools, the respondents were asked to respond if they have experienced disciplinary cases in schools and mention them, then asked if they relate with students' mobile phones use. The respondents were teachers, discipline masters, students and school boards chairpersons. Disciplinary case is one of the barriers in secondary schools which can affect the achievement of the school planned educational and administrative objectives. Findings show that, disciplinary cases differ from school to school or from one student to another depending on numerous factors like strategies used by teachers and also child upbringing. The findings reveal that majority $88 \%$ of teachers responded "Yes", they have experienced disciplinary problems, while minority $13 \%$ of the teachers said "No". For discipline teachers, all responded "Yes" that they have experienced disciplinary problems while none of them said "No". The findings also indicate that, secondary schools in Moshi Municipal have discipline problems to the extent that teachers and other educational stakeholders can notice them and it impacts in running various activities in the school. The explanation given to support, $71 \%$ of the teachers and $80 \%$. Discipline master said "Most of the students are in adolescent stage, stubborn, not following school rules, also influenced by peer pressure to commit indiscipline cases". The remaining $29 \%$ of the teachers and $20 \%$ Discipline masters said "students come from different society, culture and family background with different behaviours". This reveals that apart from being in adolescence, culture, society and family differences contribute to indiscipline cases occurred in secondary schools.

The finding concurs with findings of Kisusange \& Shauri (2007), which found that there is association between children age, growth and the behaviour of adolescents. This is the age of foolishness where children change their behaviours and they don't reason if it is bad or good behaviours. Therefore, parents and teachers need to be careful and be 
strictly in shaping and educating these children. Meanwhile, the respondents were asked to mention the disciplinary cases most reported in their school, the responses are shown in table 6;

\begin{tabular}{|c|c|c|c|c|}
\hline & \multicolumn{2}{|c|}{ Teachers } & \multicolumn{2}{c|}{ Discipline Master } \\
\hline & Frequency & Percent & Frequency & Percent \\
\hline Truancy & 21 & 70 & 7 & 88 \\
\hline Sexual affairs & 19 & 63 & 6 & 75 \\
\hline Violence/ bullying/ fighting & 13 & 43 & 5 & 63 \\
\hline Using mobile phone in school & 11 & 37 & - & - \\
\hline Alcoholism & 9 & 30 & 3 & 38 \\
\hline Pregnancy cases & 8 & 27 & 5 & 63 \\
\hline Using abusive language & 6 & 20 & & - \\
\hline Laziness & 6 & 20 & - & - \\
\hline School strikes & 5 & 17 & - & 50 \\
\hline Improper dressing style & 5 & 17 & 4 & - \\
\hline Theft & 4 & 13 & - & 13 \\
\hline Drug abuse & 4 & 13 & 4 & - \\
\hline Disobedience and disrespect & 4 & 13 & 1 & - \\
\hline Cheating in exams & 2 & 7 & - & - \\
\hline Refusing teachers punishment & 1 & 3 & - & - \\
\hline Escaping classes and school & 1 & 3 & & \\
\hline
\end{tabular}

Table 2: Students' Disciplinary Cases Most Reported in Secondary Schools iun

Moshi Municipality; Teacher; $(\mathrm{N}=32)$ and Discipline Masters Responses; $(\mathrm{N}=8)$

Source: Field 2017

The findings revealed that, schools are experiencing a wide range of disciplinary problems. It was indicated that truancy was one of the highest disciplinary case experienced in secondary schools as pointed out by $70 \%$ of teachers and $88 \%$ of discipline masters, followed by sexual behaviours responded by $63 \%$ of teachers and $75 \%$ of discipline masters and violence by $43 \%$ of teachers and $63 \%$ of discipline masters. Other disciplinary cases pointed out were the use of mobile phones in school, pregnancy cases, alcoholism, and use of abuse language, as shown in table 2.

It is evident also from the document analysis schedule, that secondary schools in Moshi Municipal are experiencing disciplinary problems. For example, in 2016, seventy-two (72) students were suspended from their schools due to truancy while twenty-six (26) students from sampled secondary schools in Moshi Municipal were suspended from school due to mobile phone use and 40 for sexual behaviours. These findings could be supported by Temitayo, Nayaya, \& Lukman (2013) findings revealed out that Truancy; Fighting; Dress code violations; theft; and leaving campus without permission are the disciplinary problems experienced in secondary schools.

\begin{tabular}{|c|c|c|c|c|}
\hline & \multicolumn{2}{|c|}{ Teachers } & \multicolumn{2}{c|}{ Discipline Masters } \\
\hline & Frequency & Percent & Frequency & Percent \\
\hline Truancy & 11 & 37 & 3 & 38 \\
\hline Mobile phone use & 23 & 77 & 8 & 100 \\
\hline Laziness & 16 & 53 & 5 & 63 \\
\hline Teachers' poor handling of students & 8 & 27 & 2 & 25 \\
\hline No parent's cooperation/ poor parental care & 7 & 23 & 3 & 38 \\
\hline Delaying in completing assignment & 3 & 10 & 1 & 13 \\
\hline Peer groups & 3 & 10 & - & - \\
\hline Adolescent stage & 1 & 3 & - & - \\
\hline
\end{tabular}

Table 3: Disciplinary Cases in Secondary Schools in Moshi Municipal

Responses from Teachers and Discipline Masters

Source: Field Data 2017

Table 3 supports the findings above as most of the respondents agree that Mobile phone is the most source of indiscipline in schools. 77\% teachers and 100\% Discipline masters agree that mobile phone is the most causative of indiscipline in secondary school; others are laziness 53\% teacher and 63\% discipline masters. Other sources are truancy, and teachers' poor handling of students. This revealed mobile phone to be a source of a lot of occurring disciplinary cases in secondary schools.

These findings line up with the findings of Kennedy, Judd, Churchward, \& Gray, (2008) that students through the use of mobile phones and computer are at risk for social isolation and sometimes turn to risky internet sites and blogs for help that may promote substance abuse, unsafe sexual practices, or aggressive or self-destructive behaviours Thus there was a clear indication that availability of social media in mobile phones and computer influences behaviour among students. 


\begin{tabular}{|l|c|c|c|}
\hline \multicolumn{2}{|c|}{} & Frequency & Percent \\
\hline \multirow{2}{*}{ Use mobile phone } & Yes & 97 & 77 \\
\cline { 2 - 4 } & No & 29 & 23 \\
\hline \multirow{3}{*}{ Phone your using } & Mine & 70 & 67 \\
\cline { 2 - 4 } & Friend & 8 & 8 \\
\cline { 2 - 4 } & Parent & 7 & 18 \\
\cline { 2 - 4 } & Others & 2 & 2 \\
\hline & At school & 3 & 5 \\
\hline & Friends' home & 3 \\
\hline
\end{tabular}

Table 4: Students Using Mobile Phones in Secondary Schools: Students' Response

Source: Field Data 2017

In Table 4 show that most of the students are using mobile phone as $77 \%$ said 'Yes' they are using it and few 23\% said 'No' means they're not using it. This reveal that mobile phones though are prohibited in schools still students are using it at home, school and friends at home as shown in the Table 4. Also, most of the students own/ possess mobile phones as $67 \%$ students agreed they own mobile phones and minority $18 \%$ use their parents' mobile phones and $8 \%$ use friends' phones. The majority who are using mobile phone at home $91 \%$ they say; they feel free and allowed to use it at home compare to school where is prohibited. This reveals that parents allow their children to use mobile phone and sometime buy mobile phones for them.

This is also evidenced by Twebaze (2015) found that majority of the students $85 \%$ who said they own mobile phones said they had been given by their parents while few said they had bought them on their own or being offered by relatives. Through frequent using mobile phones and accessing video like pornography or violence video the students imitate what he/ she observed which lead to students engaging in fighting teachers and sexual behaviours and the like.

The findings also concur with Eysenck, and Nias, (1978) findings, who found that violent and sexually-explicit media have physiological effects that induce aggressive behaviours. Likewise, Johnson, Cohen, Smailes, Kasen, \& Brooks, (2002) focus on the ways in which mobile phone violence primes or cues pre-existing aggressive thoughts and feelings. They believe these thoughts are already imbedded in the adolescent and seeing the images on phones only increases the rates and intensities of anti-social thoughts.

\begin{tabular}{|c|c|c|c|c|}
\hline & \multicolumn{3}{|c|}{ Teachers } & Discipline masters \\
\hline & Frequency & Percent & Frequency & Percent \\
\hline Learning material & 3 & 10 & 1 & 13 \\
\hline Social media (WhatsApp, Facebook, tweeter etc.) & 30 & 97 & 8 & 100 \\
\hline Normal calls and text messages & 18 & 58 & 5 & 63 \\
\hline Downloading video clip on pornography, music, violence video & 4 & 13 & 1 & 13 \\
\hline
\end{tabular}

Table 5: Contents Mostly Accessed by the Students when Using Mobile Phones,

Teachers and Discipline Masters Response

Source: Field Data 2017

Table 5 show the contents students' access when using mobile phone $97 \%$ teachers and $100 \%$ discipline masters agreed Social media (WhatsApp, Facebook, tweeter etc.) to be the most accessed content. Through these social media students send each other different video of violence, pornography, music, through viewing these videos they imitate a lot of indiscipline.

\subsection{Contents Mostly Accessed by the Students When Using Mobile Phones, Students Response}

Findings show that students' use mobile phone in communicating with friends as the most accessed content. Thus, students use mobile phone to communicate with friend. Through communicating they find themselves involving in sexual affairs easily as they use phones to communicate with their partners. Some $26 \%$ of student said they are using for learning, though few $10 \%$ of teachers and 13\% discipline masters agreed that students are using mobile phones for learning as when they caught students using mobile phones most, they don't find learning material in the device rather than bad pictures, videos and music.

The study findings concur with the finding of the study done by Ford \& Batchelor, (2007) found students spend most of the time chatting, recording fights and violence and watching pornography and musicians' clips, where they also learn bad behaviours by trying to act what they have seen. 


\begin{tabular}{|c|c|c|c|c|c|c|}
\hline Descriptive Statistics & \multicolumn{2}{|c|}{ Students } & \multicolumn{2}{c|}{ Teachers } & \multicolumn{2}{c|}{ Discipline Masters } \\
\hline & Mean & Std. & Mean & Std. & Mean & Std. \\
\hline Obedience and respect & 3.03 & 1.45 & 2.78 & 1.45 & 1.50 & 0.53 \\
\hline Friendliness & 4.02 & 1.12 & 4.00 & 1.08 & 4.25 & 0.71 \\
\hline Sexual behaviours & 3.63 & 1.32 & 4.00 & 1.37 & 4.88 & 0.35 \\
\hline Hardworking & 2.74 & 1.40 & 2.47 & 1.19 & 1.13 & 0.35 \\
\hline School strikes & 2.79 & 1.29 & 3.60 & 1.04 & 4.75 & 0.46 \\
\hline Poor performance & 3.40 & 1.48 & 3.44 & 1.48 & 4.63 & 0.52 \\
\hline Drug abuse & 2.74 & 1.46 & 3.59 & 1.48 & 4.63 & 0.74 \\
\hline Increase student's attendance in school & 2.37 & 1.35 & 2.39 & 1.31 & 1.25 & 0.46 \\
\hline Truancy & 3.27 & 1.23 & 3.56 & 1.32 & 4.13 & 0.64 \\
\hline Alcoholism & 3.02 & 1.48 & 3.69 & 1.38 & 4.63 & 0.74 \\
\hline Violence & 3.00 & 1.34 & 3.66 & 1.41 & 4.50 & 0.53 \\
\hline Improper Dressing styles & 3.52 & 1.46 & 3.81 & 1.51 & 4.75 & 0.71 \\
\hline Search education info & 3.61 & 1.26 & 3.09 & 1.44 & 1.63 & 1.06 \\
\hline Improved performance & 3.21 & 1.39 & 2.80 & 1.45 & 1.63 & 0.74 \\
\hline $\begin{array}{c}\text { Spent much time in downloading learning } \\
\text { material than involved in bad behaviour }\end{array}$ & 3.05 & 1.49 & 2.84 & 1.61 & 1.38 & 0.52 \\
\hline Improved learning activities & 3.46 & 1.35 & 2.91 & 1.42 & 1.38 & 0.52 \\
\hline
\end{tabular}

Table 6: Influence of Mobile Phone Use Have On Students' Behaviours' in

Secondary Schools; Students, Teachers and Discipline Masters Responses Source: Field Data 2017

The findings in table 6 reveal that majority of the students were agreed that the use of mobile phone had an influence on friendliness $(\overline{\mathrm{x}}=4.02$, std $=1.45)$ while minority argued that mobile phone usage influence sexual behaviour $(\bar{x}=3.63$, std $=1.32)$, leads to poor performance $(\bar{x}=3.4$, std $=148)$ and others agreed that the use of mobile phone influence the search of education information $(\overline{\mathrm{x}}=3.61$, std $=1.26)$. The findings also have shown that students were not agreed the usage of mobile phone to had an influence on hard working $(\overline{\mathrm{x}}=2.74$, std $=1.4)$, school strikes $(\overline{\mathrm{x}}=2.74$, std $=$ $1.29)$, and drug abuse $(\bar{x}=2.74$, std $=1.46)$. Most of students neither agreed nor disagreed on the usage of mobile phone by students to have an influence on obedience and respect $(\bar{x}=3.03$, std $=1.45)$, truancy behaviour $(\bar{x}=3.27, \operatorname{std}=1.23)$ and alcoholism $(\overline{\mathrm{x}}=3.02$, std $=1.48)$.Therefore, findings of the study shows that mobile phone to students influence friendship, sexual behaviours and also lead to poor performance. Through friendship student engage much on sexual affairs and this is stimulated by what they observed on internet through mobile phones like pornography video and pictures.

\subsection{Teachers' Response}

The study found that majority of teachers were agreed that the students usage of mobile phone had an influence on the friendliness $(\bar{x}=4.00$, std $=1.08)$, sexual behaviour $(\bar{x}=4.00$, std $=1.37)$ and improper dressing style $(\bar{x}=3.81$, std $=$ 1.51) minority were agreed that mobile phone usage influence school strike $(\overline{\mathrm{x}}=3.60$, std $=1.04)$, poor performance $(\overline{\mathrm{x}}=$ 3.44 , std $=1.48)$, drug abuse $(\bar{x}=3.59$, std $=1.48)$ and violence $(\bar{x}=3.66$, std $=1.41)$. Teachers also disagreed that the mobile phone usage influence hard working $(\overline{\mathrm{x}}=2.47$, std $=1.19)$, increase students attendance in school $(\overline{\mathrm{x}}=2.39$, std $=$ 1.31), improve performance $(\bar{x}=2.80$, std $=1.45)$, Spent much time in downloading learning material than involved in bad behaviour $(\bar{x}=2.84, \operatorname{std}=1.61)$, influence obedience and respect $(\bar{x}=2.78, \operatorname{std}=1.45)$.

\subsection{Discipline Masters Response}

The findings in table 4.13, show that school discipline masters' were agree to the following students behaviour which influenced by usage of the mobile phone; friendliness $(\bar{x}=4.25$, std $=0.71)$, sexual behaviour $(\bar{x}=4.88$, std $=0.35)$, school strikes $(\bar{x}=4.75$, std $=0.46)$, poor performance $(\bar{x}=4.63$, std $=0.52)$, drug abuse $(\bar{x}=4.63$, std $=0.74)$ and improper dressing style $(\bar{x}=4.75$, std $=0.71)$. On other hand discipline masters response have shown that they don't believe that the students mobile phone usage influence obedience and respect $(\overline{\mathrm{x}}=1.50$, std $=0.53)$, hardworking $(\overline{\mathrm{x}}=1.13$, std $=0.35)$, increase student attendance in $\operatorname{school}(\overline{\mathrm{x}}=1.26$, std $=0.46)$, improve performance $(\overline{\mathrm{x}}=1.63$, std $=0.74)$.

The School Boards Chairpersons were also asked to rate the statements concerning students' behaviours if they are being influenced by students' mobile phone use. The responses are summarized on table 4.14; 


\begin{tabular}{|c|c|c|c|c|c|c|}
\hline Statements & \multicolumn{2}{|c|}{ Teacher } & \multicolumn{2}{|c|}{ Parent } & \multicolumn{2}{|c|}{ Discipline } \\
\hline & Mean & Std. & Mean & Std. & Mean & Std. \\
\hline $\begin{array}{c}\text { Sometimes some students perform poorly } \\
\text { because they spent too much time using } \\
\text { mobile phone }\end{array}$ & 4.06 & 1.413 & 4.00 & 1.309 & 5.00 & 0.000 \\
\hline $\begin{array}{l}\text { Mobile phones should be totally banned in the } \\
\text { schools to promote student's behaviour }\end{array}$ & 3.75 & 1.545 & 3.75 & 1.753 & 4.38 & 1.408 \\
\hline $\begin{array}{l}\text { Mobile phone can be allowed in schools and } \\
\text { used by the students as any other learning } \\
\text { device }\end{array}$ & 2.45 & 1.524 & 2.63 & 1.598 & 1.50 & .535 \\
\hline $\begin{array}{l}\text { Students perform well on their exams as they } \\
\text { use mobile phone to download education } \\
\text { material }\end{array}$ & 2.41 & 1.478 & 2.88 & 1.246 & 1.63 & .518 \\
\hline $\begin{array}{l}\text { There is relationship between mobile use and } \\
\text { student's behaviour }\end{array}$ & 4.23 & 1.087 & 2.43 & 1.397 & 2.25 & 1.165 \\
\hline Students become Obedience and respect & 2.61 & 1.430 & 2.43 & 1.272 & 1.63 & .518 \\
\hline $\begin{array}{c}\text { Playing violent video games makes students } \\
\text { violent }\end{array}$ & 3.88 & 1.454 & 3.88 & .835 & 4.13 & .354 \\
\hline $\begin{array}{c}\text { Watching sexy movies makes students sex } \\
\text { crazy }\end{array}$ & 4.09 & 1.467 & 3.57 & 1.397 & 4.25 & 1.035 \\
\hline $\begin{array}{l}\text { Mobile phones should be used under the } \\
\text { guidance of teachers }\end{array}$ & 2.78 & 1.560 & 4.38 & 1.061 & 2.00 & 1.069 \\
\hline $\begin{array}{l}\text { Listening to violent and romantic music } \\
\text { encourages violence and early sexual } \\
\text { practices among students }\end{array}$ & 3.75 & 1.481 & 4.50 & .926 & 4.25 & .463 \\
\hline $\begin{array}{l}\text { Viewing beer commercials, contest and } \\
\text { celebrities encourages students towards } \\
\text { using drug and substance abuse. }\end{array}$ & 3.91 & 1.422 & 3.75 & 1.282 & 4.75 & .463 \\
\hline
\end{tabular}

Table 7: Perceptions of Teachers and Parents on the Effects of Mobile Phone Use by Their Students Source: Field Data 2017

\subsection{Student Performance}

The results in table 4.15 show that teachers $(\overline{\mathrm{x}}=4.06$,) and parent representatives $(\overline{\mathrm{x}}=4.00)$ were agreed while all discipline masters were strongly agreed $(\overline{\mathrm{x}}=5.00)$ that sometimes some students perform poorly because they spent too much time using mobile phone. Furthermore, both teachers $(\overline{\mathrm{x}}=2.41)$, parent representatives $(\overline{\mathrm{x}}=2.88)$ and discipline masters $(\bar{x}=1.63)$ disagreed that students perform well on their exams as they use mobile phone to download education material. These findings concur with Kibona \& Mgaya (2015) findings that reveal the impact of smart phone on the academic performance of students, in which the results have revealed that the smart phone bring negative results or progression on students' performance academically.

\subsection{Mobile Phone Usage in Relation to Student Behaviour}

Based on the results in table 4.15 study findings reveal that while teachers $(\overline{\mathrm{x}}=4.23)$ agreed that there exist a relationship between the students mobile phone usage and their behaviour, most of parent $(\overline{\mathrm{x}}=2.43)$ and discipline masters $(\overline{\mathrm{x}}=2.25)$ thought that there is no relationship between those two variables (student mobile phone usage and student behaviour).

This finding related with Burning and Moss (2012) findings that argued that banning of mobile phones aims at improving students' behaviour. Most of the schools ban students from using mobile phones; they argue that students spent a lot time chatting, recording fights, watching pornography and chatting through social networks instead of concentrating to their studies and home works given at school.

\begin{tabular}{|c|c|c|}
\hline & Frequency & Percent \\
\hline Students lose concentration in class & 5 & 21 \\
\hline Misbehaviour such as improper dressing styles, violence, sexually affairs etc. & 21 & 88 \\
\hline Poor performance as student spent much time chatting in mobile phone & 10 & 42 \\
\hline Students disobeying teachers & 7 & 29 \\
\hline Fail to complete their homework on time & 2 & 8 \\
\hline Enmity with parents when expel their children caught with mobile phone at school & 1 & 4 \\
\hline Difficult to monitor the time they are using mobile phone at school & 3 & 13 \\
\hline
\end{tabular}

Table 8: Challenges Facing Teachers as the Results of Mobile Phone Use; Teachers Response

Source: Field Data 2017 
Mostly occurring challenge was 'student misbehaviour such as improper dressing styles, violence, sexually affairs etc. 88\% teachers reasoned that teachers feel happy when their students have good behaviour and feel so bad and not working in good way if their students misbehave. Other challenges include poor performance as student spent much time chatting in mobile phone, students disobeying teachers, Students lose concentration in class as most mentioned by respondents.

Generally, both respondents (discipline masters, teachers, School Board Chairpersons, and parents) agreed that teachers face challenges as a result of students' mobile phone use in secondary schools. The challenges mostly mentioned by each respondent are as follows; 'student misbehaviour such as improper dressing styles, violence, sexually affairs etc', Poor performance as they spent a lot of time chatting on mobile phones, failure to complete their home works given by their teachers and Students lose concentration in classroom, sleeping in classroom due to night chatting.

These findings concur with Kihwele, (2013) findings, that students are spending much time dealing with phones than with studies. Other school regulations are broken; learning concentration is shifted away from studies. Owning mobile phone while school rules restrict is a sign of misbehaviour; and often leads to further misbehaviours like being at a wrong place in order to get space to use the phone secretly. These bring challenges to the teachers in handling discipline in schools.

\begin{tabular}{|c|c|c|}
\hline & Frequency & Percent \\
\hline Guidance and counselling on the use of mobile phone & 3 & 10 \\
\hline Keep the students busy with homework's & 1 & 3 \\
\hline Mobile phone should be banned in school & 12 & 41 \\
\hline $\begin{array}{c}\text { Inspections of mobile phone at school } \\
\text { school phone to be used at home and at }\end{array}$ & 13 & 45 \\
\hline Strict rules like totally expelled from school when caught with mobile phone & 12 & 41 \\
\hline Educate the students on proper use of mobile phone & 8 & 28 \\
\hline $\begin{array}{c}\text { The ministry should allow the use of mobile phone as teaching and learning } \\
\text { device }\end{array}$ & 6 & 21 \\
\hline Teachers should guide the students on the use if mobile phone will be allowed & 3 & 10 \\
\hline $\begin{array}{c}\text { The school should have a mobile phone for students use to communicate with } \\
\text { their parents }\end{array}$ & 1 & 3 \\
\hline
\end{tabular}

Table 9: Solutions to Control Students' Behaviour in Relation to

Mobile Phone Use in Secondary School; Teacher Response

Source: Field Data 2017

\section{Summary of the Findings}

\subsection{Students' Disciplinary Cases Experienced In Secondary Schools in Moshi Municipality}

The findings showed that the most and common disciplinary cases found in secondary schools in Moshi Municipal are: truancy, sexual behaviours, violence/ fighting, using mobile phones in school, alcoholism, the use of abuse language, smoking, and pregnancy cases. Also, the findings show that most of disciplinary cases found in secondary schools in Moshi Municipal are associated with students using mobile phones.

\subsection{Contents do Students Mostly Access when Using Mobile Phone in Secondary Schools}

The Social media (WhatsApp, Facebook, tweeter etc.) has been revealed to be the most accessed content. Through these social media students send each other different video of violence, pornography, music, through viewing these videos they imitate a lot of indiscipline. Also, they use it for communications with friend, downloading pornography, violence movies and music video

\subsection{Influence Does the Mobile Phone Use Have on Students' Behaviour in Secondary Schools}

Majority of the respondents i.e. teachers, discipline masters, students and school board chairpersons agreed that the students' mobile phone usage influence their behaviours negatively like friendliness, encourage sexual behaviour, improper dressing style school strikes and poor performance as well as truancy, alcoholism and violence.

\subsection{Perceptions of Teachers' and Parents' on the Effects of Mobile Phone Use on Students' Behaviour in Secondary Schools}

The researcher grouped the perception into three groups after being analysed and reveals the following; thus, both parent and teacher perceive that students perform poorly in exams because they spent too much time using mobile phone instead of studying. They both ignore that student perform well as they use the gadget to download learning material.

Parents and teachers also ignore to allow students to use mobile phones in school like other learning device (computer). They say that mobile phones should be totally banned in school to promote students' behaviour. The study also reveals that teachers perceive that there is relationship between mobile phone use and students' behaviours while the parents ignore it. 


\subsection{Challenges Facing Teachers As the Results of Mobile Phone Use by Their Students in Secondary Schools}

The study findings showed that the main challenges experienced are: Both respondents (discipline masters, teachers, School Board Chairpersons, and parents) reveal that teachers face challenges as a result of students' mobile phone use in secondary schools. The challenges mostly mentioned by each respondent are as follows; 'student misbehaviour such as truancy, improper dressing styles, violence, sexually affairs etc', Poor performance as they spent a lot of time chatting on mobile phones, failure to complete their home works given by their teachers and Students lose concentration in classroom, sleeping in classroom due to night chatting.

\subsection{Solutions can be used to Control Students' Behaviour in Relation to Mobile Phone Use in Secondary Schools}

The study findings showed that the main solutions suggested are; the school to have severe punishment or total expulsion of students caught using mobile phones, involve parents, teachers, religious leaders and other education stakeholders in prohibiting and educating students from using mobile phones, Ministry of Education to find proper way to allow the use of mobile phone in teaching and learning, strict inspections of mobile phone at school by the teachers and parents at home, parents should stop providing mobile phone to their children, and lastly to educate the students on proper use of mobile phone even if is not used in schools.

\section{Conclusions}

Based on the findings of the study, the researcher concluded that students' mobile phone use influences discipline among secondary school students. The researcher observed that with the current trend in technology, one needs to be informed posing a challenge to the young generation on the risk and benefits associated with mobile phone use. Equally, the study has shown that mobile phone use by students was associated with both positive and negative effects on their behaviour. The researcher observed that negative effects overweighed positive effects.

The solutions, if worked out well, will help to address the issue of mobile phone use in schools. Mobile phones have to be used in teaching and learning in secondary schools due to their usefulness. Students have to be more educated on the proper use of mobile phones so as to reduce the consequences of their improper use. Teachers need to inform students why they ban mobile phones in schools and parents need to inform why they allow their children to access mobile phones. Teachers and parents have to work collaboratively in ensuring that students are using mobile phones appropriately. This will foster development of value-based mobile phone, because continue banning the mobile phone use in school while students are using it will increase indiscipline cases as revealed on the study. The findings indicate that the majority of the students use or own mobile phones at home.

\section{Recommendations}

In view of the above discussion and conclusions, this study recommends the following that would be beneficial to the educational stakeholders like students, teachers, parents and government;

Teachers, parents, religious leaders and other education stakeholders need to work in collaborative to inform students about the harmful effects of mobile phones for which the current generation of young people seem to be attracted to and even sometimes demanding to access them. This is because most of the students who participated in this study were between age 14 and 20 years hence, they shared the same characteristics as the adolescents. This group of people like adventuring and discovering so as to fulfil their curiosity. Thus, through using mobile phones students imitate what they access like; dressing style, sexual behaviour and the like.

The Ministry of Education should encourage and remove the ban of mobile phones and be a part of school curricula. The students will be able to analyze content on unwanted behaviours such as sexual content, violence and drug and substance abuse which they like imitating. They will use as a device for learning and being monitored and educated on the proper use, will minimize indiscipline cases associated with mobile phones.

\section{Suggestion for Further Research}

The researcher proposes further research on the following areas:

- This study was carried out in town area, similar study can be carried out in other areas especially in rural in order to see if researchers can make generalization of the results.

- The further research can be done on the methods that will help the Ministry of Education to allow the use of mobile phones in school from primary school.

\section{References}

i. Aguero, A. (2009). Education, mobile phones use and production decisions: A rural case study in Peru. In PreConference Workshop at the International Communications Association Conference (pp. 1-13), Chicago, Illinois.

ii. Almu, A. \&Buhari, B. (2014). Effect of Mobile Social Networks on Secondary Schools students, Sokoto. Dept. of Mathematics, Computer Science Unit, Usman Danfodiyo University; Sokoto, Nigeria.

iii. Bandura, A. (1969). Social learning theory of identification proceeds: Chicago: Rand Mcnally.

iv. Bandura, A. (1977). Social learning theory. Englewood Cliffs, NJ: Prentice-Hall.

v. Barkham, P\& Moss, S (2012). Should mobile phone be banned in Schools? The Gurdian, p.8

vi. Battistich, V. (2005). Character education, prevention and youth development

vii. Bertalanffy, L., von (1968). General systems theory. New York: Braziller.

viii. Borg, W.R \& Gall J.P (2003) Education Research: An Introduction; Seventh Edition. White Plains, NY: Longman 
ix. Cohen, L., Marrion, L.\& Marrison (2000) Research Methods in Education (5 $5^{\text {th }}$ ed.). London: Routledge/ Falmer

x. Denniston, M. M., Swahn, M. H., Hertz, M. F., \& Romero, L.M., (2007). Associations between Electronic Media Use and Involvement in Violence, Alcohol and Drug Use among United States high school students. Atlanta.

xi. Disney Cooperation (2007). Disney Mobile phone survey. Teen \& Tween Cell phone calls rise during the summertime. Retrieve on 2nd Feb, 2017 from http/ / www.highbeam.com/ doc/ 1P1-141706505.html

xii. Dowell, B. Burgess, A.W., \& Cavanaugh, D.J. (2009). Clustering of internet risk behaviors in a middle school student population. Journal of School Health, 79(11), 547-553

xiii. Johnson, M., Earles, K.A., Alexander, R., Liverpool. J. \& McGhee, A. (2002). Media Influences on Children and Adolescents: Violence and Sex. Journal of the national medical association 9 (94), 797-801. Atlanta, Georgia.

xiv. Eysenck, H.J. and D.K.B. Nias. (1978). Sex, Violence, and the Media. New York: Saint Martin's Press

xv. Ford, M. and Batchelor, J. (2007). From Zero to Hero: Is the Mobile Phone a Viable Learning Tool for Africa? 3rd International Conference on Social and Organisational Informatics and Cybernetics. SOIC 2007, Orlando.

xvi. Geoffrey A.M. (2014). Media and Sexual Behaviour of Secondary School Students: A Case of Arusha Municipality. Dissertation Submitted for the Award of Master of Arts in Rural Development. SUA. Morogoro, Tanzania.

xvii. Hannah, R (2010). Head Teachers' search power to be toughened. BBC News Education Report.

xviii. Izahacki, C. (2006). Female adolescents' knowledge on homosexual relationship and the effects in leading. The case of Moshi Rural District. (Unpublished M.A. Dissertation). University of Dar es Salaam.

xix. Jeng, A. (2011. Indiscipline in schools: The Daily Observer. Retrieved February, 2017 http:/ / www.observer.gm>Africa>Gambia.

xx. Johnson, J. G., P. Cohen, E.M. Smailes, S. Kasen and J.S. Brook. (2002). Aggressive behaviour during adolescence and adulthood. Science.

xxi. Katz, E., Blumler, J. G., \&Gurevitch, M. (1973). Uses and gratifications research. The Public Opinion Quarterly, Beverly Hills, CA: Sage.

xxii. Kennedy, G. E., Judd, T. S., Churchward, A., \& Gray, K. (2008). First year students' experiences with technology: Are they really digital natives? Australasian Journal of Educational Technology, 24. (1), 108-122

xxiii. Kibona, L. \& Mgaya, G. (2015) Smart Phones' Effects an Academic Performance of Higher Learning Students. A Case of Ruaha Catholic University -Iringa, Tanzania. Journal of Multidisciplinary Engineering Science and Technology.

xxiv. Kihwele, E. J (2013) The Perceptions of Teachers, Parents and Students on the Effects of Mobile Phone Use on Student Learning in Tanzania. UDOM, Dodoma, Journal of Education and Practice Vol.4, No.25.

xxv. Kisusange, C. L. \& Shauri, S. P. (2007). Conflict and Conflict Resolution in Secondary Schools: Paper Presented at Tanzania Head of Schools Conference. Ubungo Plaza Dar es Salaam 22 nd September 2007

xxvi. Kwajo, (2011). Teachers sleep with students at Wesley Girls Senior High school.

xxvii. Lepp, A, Backley.J. E, Karpinski, A.C (2015) The Relationship Between Cell Phone use, Academic Performance, Anxiety, and Satisfaction with Life in College Students. Kent; USA.

xxviii. Leyden, A. (2015). 40 uses for Smart Phones in School. Retrieved on 2nd February 2017 from http;/ / www.examtime.com/ blog/ 40 -uses-for-smartphones-in-school.

xxix. Ministry of Education and Vocational Training [MoEVT] (1995) Tanzania Education \&Training policy. United Republic of Tanzania.

xxx. Ndeto, A. (2013) Effectiveness of School Rules and Regulations in enhancing Discipline in Public Secondary Schools in Kangundo Division, Machakos County, Kenya.A Thesis Submitted for the Award of the Degree of Master of Education in Educational Administration and Planning, Catholic University of Eastern Africa

xxxi. Santrock, J.W. (2010). Adolescence. McGraw-Hill, New York.

xxxii. Schooler, D., Sorsoli, L., Kim, J. L, \& Tolman, D.L. (2009). Adolescents' use of sexual media. Journal Research on Adolescence, 19(3), 484-508.

xxxiii. Simatwa, E.M.W (2012). Management of students discipline in secondary schools in Kenya: A case study of Bungoma County. International Research Journals 3(1), 172-189.

xxxiv. Skinner B.F. (1938) The Behaviour of Organisms: D. Appleton \& company.USA

xxxv. Ssenkabirwa, A. (2013). Students free to use mobile phones at school-government. Sunday Monitor: March 1st 2013.

xxxvi. Temitayo. Nayaya, M.A. \& Lukman, A.A. (2013). Management of Disciplinary Problems in Secondary Schools: Jalingo Metropolis in Focus, Volume 13 Issue 14 Version 1.0 Year 2013, Global Journals Inc. USA

xxxvii. Twebaze, R.M (2015). Mobile Phone use in Uganda's Boarding Secondary schools: A case o study of Bushenyi District. Journal of Educational studies, Trends and Practices.

xxxviii. URT (2002) Waraka wa Elimu Namba 11 wa Mwaka 2002; Kuanzisha Huduma za Malezi na Ushauri Nasaha kwa Wanafunzi katika Shule na Vyuo vya Ualimu. Dar Essalaam, MoEVT.

xxxix. URT(2011). Basic Education Statistics in Tanzania [BEST]. National \& Regional Data. MoEVT, Dar essalaam; Tanzania. 